\title{
Epstein-Barr Virus WZhet DNA Can Induce Lytic Replication in Epithelial Cells in vitro, although WZhet Is Not Detectable in Many Human Tissues in vivo
}

\author{
Julie L. Ryan ${ }^{a}$ Richard J. Jones ${ }^{b}$ Sandra H. Elmore ${ }^{c}$ Shannon C. Kenney ${ }^{d}$ \\ George Miller $^{f}$ Jane C. Schroeder ${ }^{e, g}$ Margaret L. Gulleyc, e \\ a Departments of Dermatology and Radiation Oncology, University of Rochester Medical Center, Rochester, N.Y., \\ ${ }^{b}$ Department of Lymphoma and Myeloma, University of Texas M.D. Anderson Cancer Center, Houston, Tex., \\ 'Department of Pathology and Laboratory Medicine, University of North Carolina, Chapel Hill, N.C., \\ dDepartment of Medicine, Medical Microbiology and Immunology, University of Wisconsin, Madison, Wisc., \\ eThe Lineberger Comprehensive Cancer Center, University of North Carolina, Chapel Hill, N.C., fDepartment of \\ Pediatrics, Yale University School of Medicine, New Haven, Conn., and ${ }^{9}$ Department of Epidemiology, \\ University of North Carolina, Chapel Hill, N.C., USA
}

\section{Key Words}

Epstein-Barr virus $\cdot$ WZhet $\cdot$ Recombination $\cdot$ Lymphoma $\cdot$

Carcinoma $\cdot$ Replication $\cdot$ Viral load

\begin{abstract}
Objective: WZhet is a rearranged and partially deleted form of the Epstein-Barr virus (EBV) genome in which the BamH1W region becomes juxtaposed with and activates $B Z L F 1$, resulting in constitutive viral replication. We tested whether WZhet induces viral replication in epithelial cells, and we studied its prevalence in a wide range of lesional tissues arising in vivo. Methods: A quantitative real-time PCR assay targeting EBV WZhet DNA was developed to measure this recombinant form of the EBV genome. Results: WZhet DNA was undetectable in any of 324 plasma or paraffin-embedded tissue samples from patients with EBV-associated and EBV-negative disorders. These included specimens from patients with Hodgkin or non-Hodgkin lymphoma, post-transplant lymphoproliferation, nasopharyngeal or gastric adenocarcino-
\end{abstract}

ma, and infectious mononucleosis. However, WZhet DNA was detected in vitro in EBV-infected AGS gastric cancer cells. Additionally, transient transfection of infected AGS gastric cancer cells showed that viral replication could be induced by a WZhet plasmid. Conclusion: This is the first evidence that WZhet induces the EBV Iytic cycle in an epithelial cell line. Our negative findings in natural settings suggest that WZhet is a defective viral product that thrives in the absence of a host immune system but is rarely present in vivo.

Copyright $\odot 2009$ S. Karger AG, Basel

\section{Introduction}

Several forms of cancer have been linked to EpsteinBarr virus (EBV) by virtue of the presence of viral DNA or gene products in tumor cells [1-6]. The gold-standard assay for defining EBV in a tumor is EBV-encoded RNA (EBER) in situ hybridization in paraffin-embedded tissue sections, because EBER stains are sensitive and specific

\section{KARGER}

๑ 2009 S. Karger AG, Basel

Fax +41613061234 E-Mail karger@karger.ch www.karger.com www.karger.com/int
Margaret L. Gulley, MD

Department of Pathology and Laboratory Medicine

University of North Carolina, 913 Brinkhous-Bullitt Building

Chapel Hill, NC 27599-7525 (USA)

Tel. +1 919843 4595, Fax +1 919966 6718,E-Mail margaret_gulley@med.unc.edu 
for latent EBV infection, and the virus can be localized to specific cell types by microscopic interpretation. However, the sensitivity of $E B E R$ histochemical stains has been called into question by investigators who showed, by molecular and immunohistochemical assays, that EBV was present in some EBER-negative tumors [3, 5, 7-10]. These data are controversial because some laboratory assays for EBV are not designed to sensitively and specifically detect tumor-associated EBV or to distinguish it from the latent EBV normally carried by most humans in a subpopulation of benign $\mathrm{B}$ lymphocytes. In addition, the 'hit-and-run' hypothesis has been proposed to explain some of these discrepancies. This hypothesis states that segments of EBV DNA or EBV gene products are undetected in certain cells or entire tumors because portions of the EBV genome have been lost, rearranged, and/ or integrated into host chromosomal DNA $[3,6]$. For example, if the EBER gene were deleted during tumorigenesis, then the resulting tumor might be falsely diagnosed as EBV-negative if EBER hybridization were the only assay used to test for presence of the virus.

One well-known rearranged and partially deleted form of the EBV genome is called WZhet. This defective EBV genome forms self-contained replicons that multiply independently of the standard EBV genome and are capable of cell-to-cell spread [11]. In this abnormally rearranged form of EBV, large segments of viral DNA have been deleted and the remaining four portions, two from the terminal ends and two from the center of the genome, are rearranged, resulting in the juxtaposition of the otherwise distant BamH1W and BamH1Z leftward reading frame 1 (BZLF1) regions, thus the name WZhet [6]. This rearrangement results in constitutive expression of the immediate early gene protein, BZLF1, which triggers active viral replication of any intact wild-type EBV DNA that resides in the same cell [12]. Other retained sequences include the origin of viral replication, those sequences that are required for packaging viral DNA into virions, and open reading frames for BZLF1, BMLF1, and BILF1 which encode proteins that transactivate lytic gene expression [6]. It is postulated that WZhet is not just an artifact but rather a novel mechanism by which the virus can switch, via recombinatorial events, from latent to lytic phases of its life cycle [13].

WZhet DNA was first identified in the Burkitt lymphoma cell line, P3HR-1 [14-17], and it has since been detected in oral hairy leukoplakia, thymic cancer, Burkitt lymphoma, Hodgkin lymphoma, and idiopathic pulmonary fibrosis $[3,6,13,18-20]$. WZhet DNA is thought to be unstable in cells lacking wild-type EBV genome [13], but WZhet has also been detected in EBER-negative tumors suggesting that it could exist in cells lacking the gold-standard marker of latent EBV infection $[3,6,13,16$, $18,19]$.

In this study, a novel quantitative real-time PCR assay targeting EBV WZhet DNA was developed in order to measure levels of WZhet in human tissues including benign and malignant biopsy tissue and plasma from patients with various diseases, some of which are EBV-related. To show that WZhet could induce lytic viral replication, WZhet plasmid was transfected into an infected gastric epithelial cell line and levels of viral DNA were subsequently measured using Q-PCR.

\section{Methods}

Biopsy Tissue Samples

Paraffin-embedded tissue blocks $(n=287)$ were retrieved from the archives of our clinical and research laboratories under a protocol approved by our Institutional Review Board. Cases were selected to represent various normal and disease conditions, some of which were known to be EBV-related diseases. EBERpositive tissues included AIDS lymphoma $(n=5)$, AIDS-related Hodgkin lymphoma $(\mathrm{n}=3)$, Hodgkin lymphoma $(\mathrm{n}=5)$, nonHodgkin lymphoma $(n=2)$, nasopharyngeal carcinoma $(n=2)$, and post-transplant lymphoproliferative disorder (PTLD; $\mathrm{n}=3$ ). EBER-negative tissues included AIDS lymphoma ( $\mathrm{n}=7)$, AIDSrelated Hodgkin lymphoma $(\mathrm{n}=1)$, and Hodgkin lymphoma $(n=4)$.

Other paraffin-embedded tissues included 113 gastric adenocarcinomas (11 EBER-positive and 102 EBER-negative); 89 gastritis samples from adults $(n=6)$ or from adults who also had gastric adenocarcinoma elsewhere in the stomach $(n=33)$ or from children ranging in age from 2 months to 20 years $(n=50)$; normal gastric mucosa from patients undergoing gastric bypass surgery $(n=5)$; normal colon $(n=9)$; meningioma $(n=11)$; Crohn's disease $(n=9)$, and ulcerative colitis $(n=11)$. Histological sectioning and DNA extraction was performed using a manual xylene-based protocol as previously described [21]. DNA from paraffin-embedded oral hairy leukoplakia tissue $(n=8)$ was provided by Dr. Jennifer Webster-Cyriaque at University of North Carolina at Chapel Hill.

Total EBV viral load was measured by Q-PCR using a TaqMan probe targeting the $B a m H 1 W$ viral sequence as previously described [21]. A Q-PCR for the human $A P O B$ gene served to insure that at least 50 cells were represented in each reaction. In addition, $A P O B$ levels served as a normalizer by which to compare viral concentrations across tissues of diverse size by reporting viral loads as a ratio of copies of EBV DNA per 100,000 cells as previously described $[21,22]$.

\section{EBV-Encoded RNA in situ Hybridization}

In every tumor tissue, EBER in situ hybridization was performed using either a manual method with fluorescein-labeled oligonulceotide EBER probe and the Super-Sensitive Poly-HRP ISH Non-Biotin Detection Kit (Biogenex, San Ramon, Calif., 
Fig. 1. Map of the WZhet partially deleted and rearranged EBV genome. WZhet is approximately $57 \mathrm{~kb}$ in length and is composed of four previously non-adjacent segments of EBV DNA. Two larger segments come from the terminal regions and two smaller segments from the center portion of the viral genome. The two smaller segments rearrange order with inversion of BZLF1. BamH1W and BZLF1 regions, normally separated by about $55 \mathrm{~kb}$, become juxtaposed. This structural change is thought to result in constitutive activation of the immediate early gene, $B Z L F 1$, which encodes the major viral protein transactivating lytic gene expression.

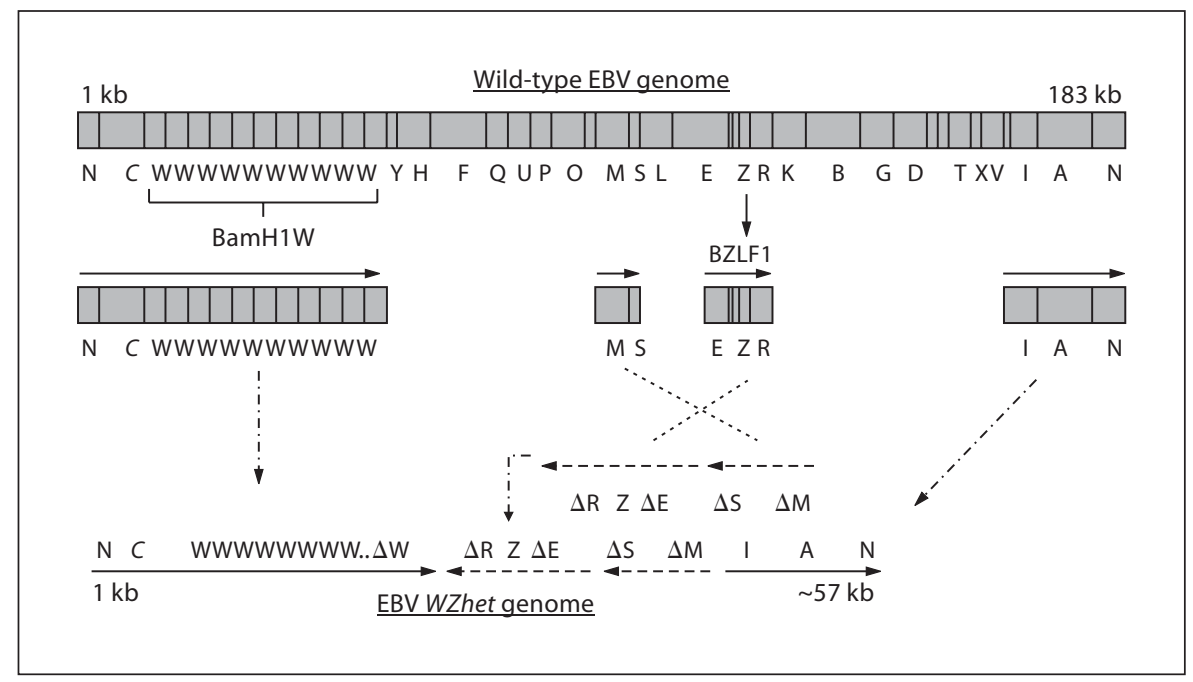

USA) with methyl green counterstain, or by an automated method using fluorescein-labeled EBER probe on the Ventana Benchmark in situ hybridization system. Oligo(d)T probe served as an RNA preservation control in both assays. A tumor was considered $E B E R$-negative if EBER staining was undetected or was expressed only in benign-appearing lymphoid cells, and EBER-positive if the signal was localized to neoplastic cells.

\section{Plasma and Blood Samples}

Frozen and fresh human plasma samples $(\mathrm{n}=37)$ having high EBV viral loads were obtained from the archives of our clinical and research laboratories. EBV viral load had been measured by Q-PCR using a TaqMan probe targeting the BamH1W viral sequence as previously described [21]. These samples came from patients with histologically proven AIDS-related lymphoma ( $\mathrm{n}=$ $10)$, post-transplant lymphoproliferative disorder $(n=6)$, or infectious mononucleosis $(n=12)$, and healthy blood donors $(n=9)$. Infectious mononucleosis was diagnosed by heterophile antibody-positivity among clinically ill patients seen by the University Student Health Service.

DNA was extracted as previously described [21]. Briefly, total DNA was purified from $200 \mu$ l of plasma using the QIAmp Blood Kit (Qiagen, Inc., Valencia, Calif., USA) following the manufacturer's protocol with elution into $50 \mu \mathrm{l}$ of AE buffer (Qiagen). Prior to extraction, the plasma was spiked with $2 \mu$ l of IPC (TaqMan ${ }^{\circledR}$ Exogenous Internal Positive Control DNA, Applied Biosystems (ABI), Foster City, Calif., USA) and this was subsequently amplified to control for the efficacy of extraction and amplification.

\section{WZhet Quantitative Real-Time Polymerase Chain Reaction}

Assay

The DNA sequence for EBV 'BamHI segment heterogeneous (het) 2.7 DNA' (WZhet; NCBI Accession No. M20820) served as the basis for designing PCR primers and a TaqMan probe spanning nucleotide numbers 1507-1655 using Primer Express 2.0 software (ABI): The forward primer targets BZLF1: 5'-GAC ATT CAT CAT TTA GAA ATG TAT CCA-3'; The reverse primer tar- gets BamH1W: 5'-TTC TCA GTC CAG CGC GTT TA-3'; TaqMan probe targets BamH1W: 5'(6FAM)TGG TCC CCC TCC CTA GAA CTG AC(TAMRA)-3'. The Q-PCR assay targets a 149-bp region of the WZhet DNA sequence as depicted in figure 1.

The standard for quantitating WZhet was a pCMVneo/WZhet plasmid that was linearized using KpnI restriction enzyme (New England Biolabs, Beverly, Mass., USA) and purified by standard ethanol precipitation. Concentration was determined by UV spectrophotometry and a stock standard was prepared at a concentration of $1 \mathrm{ng} / \mathrm{ml}$. Since each WZhet plasmid has one copy of the BZLF1 gene, the copy number of WZhet DNA in the stock aliquots could be determined using BZLF1 Q-PCR as previously described [21] on serial 10 -fold dilutions ranging from $10^{-2}$ to $10^{-7} \mathrm{ng} / \mu \mathrm{l}$ of stock. Microsoft Excel was used to obtain a linear trend line for the average BZLF1 viral loads for each serial dilution plotted against the concentration of WZhet plasmid. It was determined that the optimal standard curve for our assay relied on six serial dilutions ranging in concentration from $5 \times 10^{-2}$ to $5 \times$ $10^{-7} \mathrm{ng}$, which corresponds to $1,000,000$ to 10 WZhet DNA copies per PCR. In any given run, this curve was considered acceptable if a difference of $3.3 \pm 0.3$ cycles was demonstrated between each of the 10 -fold dilutions, and if the correlation coefficient was at least 0.99 .

Q-PCR for WZhet was performed and products were detected using an ABI Prism 7900 or 7500 Real-Time PCR instrument and Sequence Detection System software. Thermocycling conditions were: $50^{\circ}$ for $2 \mathrm{~min}, 95^{\circ}$ for $10 \mathrm{~min}, 95^{\circ}$ for $15 \mathrm{~s}$, and $60^{\circ}$ for $1 \mathrm{~min}$ for 40 cycles. Each $25-\mu$ l reaction contained: $1 \times$ TaqMan ${ }^{\circledR}$ Universal Master Mix, forward and reverse primer (15 pmol each), and TaqMan ${ }^{\circledR}$ probe $(10 \mathrm{pmol})$. DNA template volume was $1 \mu \mathrm{l}$ for paraffin-embedded tissues, and $5 \mu \mathrm{l}$ for plasma samples. To check for amplicon contamination, every run contained at least two 'no template' controls in which nuclease-free water was substituted for template. Quantification results for experimental samples were extrapolated from the standard curve. Experimental samples were run in duplicate and a mean WZhet load was calculated. 
Transient Transfection and Virion Measurements in a Cell Line Model

The AGS gastric cancer cell line (ATCC CRL-1739) was EBVinfected as previously described using a recombinant form of the EBV B95.8 strain [23-25]. This recombinant virus, courtesy of Dr. Henri-Jacques Delecluse of Heidelberg, encodes green fluorescence protein and a hygromycin $B$ resistance gene to facilitate selection of infected cells [23]. The infected clone, AGS-B95-HygB, was grown in RPMI 1640 (Gibco, Invitrogen) supplemented with $100 \mu \mathrm{g} / \mathrm{ml}$ hygromycin B (HygB) as well as $10 \%$ fetal bovine serum and antibiotics. The level of infection was determined using a battery of six EBV Q-PCR assays performed as previously described on extracted DNA $[21,26]$, and by EBER in situ hybridization performed on formalin-fixed, paraffin-embedded cell pellets that were prepared from the cell line. Immunohistochemical stains for EBV lytic proteins (BZLF1 and BMRF1) were performed using a BioGenex Super Sensitive non-biotin horseradish peroxidase detection system and BMRF1 antibody (1:200 dilution; Research Diagnostics, Inc.) or BZLF1 antibody (1:20 dilution; Argene).

To evaluate the extent to which WZhet could induce lytic viral replication, the WZhet plasmid was transfected into AGS-B95HygB gastric cancer cells and then several markers of viral replication were measured. To accomplish this, cells were plated at a density of $1.5 \times 10^{5}$ cells/well. Once they reached $60-80 \%$ confluence, transient transfection of WZhet plasmid was performed. The transfection mixture containing Lipofectamine ${ }^{\mathrm{TM}}$ Reagent (Invitrogen), $1.5 \mu \mathrm{g}$ of WZhet plasmid DNA (not linearized), and $100 \mu \mathrm{l}$ of OptiMEM (Gibco) was incubated for $30 \mathrm{~min}$ at room temperature. During preparation of the transfection mixture, the cells were starved in serum-free RPMI 1640 medium for $30 \mathrm{~min}$ at $37^{\circ}$ in a humidified atmosphere with $5 \% \mathrm{CO}_{2}$. The starvation medium was replaced with serum-free medium and the Lipofectamin ${ }^{\mathrm{TM}} /$ WZhet transfection mixture. The plates were incubated for $2 \mathrm{~h}$ at $37^{\circ}$ in a humidified atmosphere with $5 \% \mathrm{CO}_{2}$. To show that hygromycin $\mathrm{B}$ did not affect the transfection rate or the level of viral replication in the AGS-B95-HygB cells, the transfection was performed again in the presence of $100 \mu \mathrm{g} / \mathrm{ml}$ hygromycin B. Following transfection, the cells were propagated in growth media for 2 days and DNA was harvested from supernatants and cells.

Before harvesting DNA from supernatant fractions, virions were separated from naked viral DNA based on differential degradation by DNase, as previously described [22]. In short, DNA unprotected by a capsid was targeted for degradation by treating the supernatant $(200 \mu \mathrm{l})$ with $25 \mu \mathrm{l}$ DNase (DNase RQ1, Promega, Madison, Wisc., USA) for $1 \mathrm{~h}$ followed by an additional $25 \mu \mathrm{lDN}$ ase for a second hour at $37^{\circ}$. Stop Buffer (Promega) and incubation at $56^{\circ}$ served to inactivate the enzyme. DNA was isolated from cell pellets and from supernatants (DNase-treated and untreated) using the QiaAmp Mini DNA Kit (Qiagen). WZhet Q-PCR was used to verify that WZhet plasmid DNA was transfected into the cells. BamH1W Q-PCR assay was used to measure EBV DNA, and the percentage of EBV DNA remaining post-DNase treatment (e.g. virion DNA) was calculated. The human $A P O B$ Q-PCR assay was used as a control to ensure that the DNase enzyme was working efficiently.

Prevalence and Effect of Epstein-Barr Virus WZhet

\section{Results}

Assay Linearity, Sensitivity, and Reproducibility

A quantitative real-time PCR assay targeting EBV WZhet DNA was developed for sensitive and precise measurement of WZhet DNA. Using linearized plasmid as the standard, the assay was efficient as shown by a cycle difference of 3.3 or 3.4 for each serial 10-fold dilution (representing slope of the standard curve). In addition, the assay was linear across 5 orders of magnitude as shown by a correlation coefficient $>0.99$ (representing the linearity of the standard curve). The WZhet Q-PCR assay was sensitive, detecting as few as 10 copies per PCR of this defective form of the EBV genome. Reproducibility of the assay was examined by replicate testing of the linearized WZhet DNA standards at each of the six serial dilution standards in duplicate on 10 different days, and the average cycle threshold value was used to calculate a coefficient of variance of $2 \%$, suggesting that the assay is quite precise and reproducible.

\section{Undetectable EBV WZhet DNA in vivo}

A series of 287 paraffin-embedded tissue samples (39 $E B E R$-positive lesions and $248 E B E R$-negative tissues) were tested for EBV WZhet DNA by Q-PCR. These included a wide variety of lesions whose histopathologic classification and EBER status are listed in tables 1 and 2. For simplicity, only a sampling of $E B E R$-negative tumors and various benign tissues are shown in table 2. Surprisingly, WZhet DNA was not detected by the WZhet QPCR assay in any of the tissues examined in this study. A control Q-PCR targeting the human $A P O B$ gene verified that DNA had been extracted from each sample and was available for amplification. The $A P O B$ assay also serves as a gauge of the number of cells assayed from each tissue block, and in this series there was a range from 94 to 69,917 cells (mean 12,800) per tissue that was represented in the amplification reactions. These findings suggest that WZhet is not commonly found in the spectrum of lesions that was examined in vivo regardless of whether the lesion contains latent EBV (e.g. various EBER-positive lymphomas and carcinomas) or lytic EBV (e.g. oral hairy leukoplakia).

To evaluate whether WZhet DNA was circulating in the bloodstream as cell-free DNA, a series of 37 plasma samples were assayed for WZhet by Q-PCR. None of the 37 plasmas had detectable WZhet DNA to a sensitivity of 10 copies per PCR. These plasma samples were from patients with various EBV-related disorders $(\mathrm{n}=28)$ and from healthy blood donors $(n=9)$. These samples were 
Table 1. WZhet and total EBV (BamH1W) levels in EBER-positive paraffin-embedded tissues

\begin{tabular}{|c|c|c|c|c|}
\hline \multirow[t]{2}{*}{$\begin{array}{l}\text { Case } \\
\text { No. }\end{array}$} & \multirow[t]{2}{*}{ Diagnosis } & \multirow[t]{2}{*}{$\begin{array}{l}\text { Control } \\
A P O B\end{array}$} & \multicolumn{2}{|c|}{$\begin{array}{l}\text { EBV DNA } \\
\text { copies } / 100,000 \text { cells }\end{array}$} \\
\hline & & & BamH1W & WZhet \\
\hline 1 & Oral hairy leukoplakia & 1,243 & $2,624,346$ & 0 \\
\hline 2 & Oral hairy leukoplakia & 18,382 & 1,142 & 0 \\
\hline 3 & Oral hairy leukoplakia & 5,782 & 2,292 & 0 \\
\hline 4 & Oral hairy leukoplakia & 2,433 & 15,231 & 0 \\
\hline 5 & Oral hairy leukoplakia & 3,635 & 1,018 & 0 \\
\hline 6 & Oral hairy leukoplakia & 3,128 & $3,608,042$ & 0 \\
\hline 7 & Oral hairy leukoplakia & 1,180 & 297 & 0 \\
\hline 8 & Oral hairy leukoplakia & 14,732 & $6,889,764$ & 0 \\
\hline 9 & AIDS lymphoma & 915 & 125 & 0 \\
\hline 10 & AIDS lymphoma & 11,409 & 48,540 & 0 \\
\hline 11 & AIDS lymphoma & 2,228 & 631,239 & 0 \\
\hline 12 & AIDS lymphoma & 209 & 2,392 & 0 \\
\hline 13 & AIDS lymphoma & 592 & 349,493 & 0 \\
\hline 14 & Hodgkin, AIDS-related & 3,633 & 2,697 & 0 \\
\hline 15 & Hodgkin, AIDS-related & 979 & 3,575 & 0 \\
\hline 16 & Hodgkin, AIDS-related & 4,032 & 397 & 0 \\
\hline 17 & Hodgkin lymphoma & 7,666 & 75 & 0 \\
\hline 18 & Hodgkin lymphoma & 467 & 14 & 0 \\
\hline 19 & Hodgkin lymphoma & 1,803 & 86 & 0 \\
\hline 20 & Hodgkin lymphoma & 18,058 & 2,226 & 0 \\
\hline 21 & Hodgkin lymphoma & 94 & 0 & 0 \\
\hline 22 & Non-Hodgkin lymphoma & 1,501 & 41,173 & 0 \\
\hline 23 & Non-Hodgkin lymphoma & 6,178 & 58,514 & 0 \\
\hline 24 & Nasopharyngeal carcinoma & 6,935 & 250,397 & 0 \\
\hline 25 & Nasopharyngeal carcinoma & 69,917 & 23,047 & 0 \\
\hline 26 & Post-transplant LPD & 6,559 & 15,612 & 0 \\
\hline 27 & Post-transplant LPD & 2,733 & 5,269 & 0 \\
\hline 28 & Post-transplant LPD & 2,778 & 25,054 & 0 \\
\hline 29 & Gastric adenocarcinoma & 2,974 & 44,956 & 0 \\
\hline 30 & Gastric adenocarcinoma & 271 & 200,000 & 0 \\
\hline 31 & Gastric adenocarcinoma & 2,896 & 90,919 & 0 \\
\hline 32 & Gastric adenocarcinoma & 1,198 & 193,823 & 0 \\
\hline 33 & Gastric adenocarcinoma & 2,734 & 144,221 & 0 \\
\hline 34 & Gastric adenocarcinoma & 80,033 & 117,755 & 0 \\
\hline 35 & Gastric adenocarcinoma & 8,770 & 130,935 & 0 \\
\hline 36 & Gastric adenocarcinoma & 23,209 & 70,757 & 0 \\
\hline 37 & Gastric adenocarcinoma & 38,723 & 112,875 & 0 \\
\hline 38 & Gastric adenocarcinoma & 5,623 & 44,496 & 0 \\
\hline 39 & Gastric adenocarcinoma & 2,812 & 64,047 & 0 \\
\hline
\end{tabular}

Table 2. WZhet and total EBV (BamH1W) levels in selected paraffin-embedded EBER-negative tumors and normal/benign tissues

\begin{tabular}{|c|c|c|c|c|}
\hline \multirow[t]{2}{*}{$\begin{array}{l}\text { Case } \\
\text { No. }\end{array}$} & \multirow[t]{2}{*}{ Diagnosis } & \multirow[t]{2}{*}{$\begin{array}{l}\text { Control } \\
A P O B\end{array}$} & \multicolumn{2}{|c|}{$\begin{array}{l}\text { EBV DNA } \\
\text { copies } / 100,000 \text { cells }\end{array}$} \\
\hline & & & BamHIW & WZhet \\
\hline 40 & AIDS lymphoma & 32,544 & 34 & 0 \\
\hline 41 & AIDS lymphoma & 12,626 & 8 & 0 \\
\hline 42 & AIDS lymphoma & 50,966 & 57 & 0 \\
\hline 43 & AIDS lymphoma & 41,928 & 0 & 0 \\
\hline 44 & AIDS lymphoma & 14,180 & 21 & 0 \\
\hline 45 & AIDS lymphoma & 18,094 & 6 & 0 \\
\hline 46 & AIDS lymphoma & 60,348 & 5 & 0 \\
\hline 47 & Hodgkin, AIDS-related & 11,660 & 17 & 0 \\
\hline 48 & Hodgkin lymphoma & 1,551 & 0 & 0 \\
\hline 49 & Hodgkin lymphoma & 643 & 0 & 0 \\
\hline 50 & Hodgkin lymphoma & 4,203 & 0 & 0 \\
\hline 51 & Hodgkin lymphoma & 1,182 & 0 & 0 \\
\hline 52 & Gastric adenocarcinoma & 4,109 & 0 & 0 \\
\hline 53 & Gastric adenocarcinoma & 3,289 & 9 & 0 \\
\hline 54 & Gastric adenocarcinoma & 1,875 & 0 & 0 \\
\hline 55 & Gastric adenocarcinoma & 11,655 & 17 & 0 \\
\hline 56 & Gastric adenocarcinoma & 2,148 & 93 & 0 \\
\hline 57 & Gastric adenocarcinoma & 45,494 & 4 & 0 \\
\hline 58 & Gastric adenocarcinoma & 10,035 & 0 & 0 \\
\hline 59 & Gastric adenocarcinoma & 13,933 & 1 & 0 \\
\hline 60 & Gastric adenocarcinoma & 1,744 & 0 & 0 \\
\hline 61 & Gastric adenocarcinoma & 225 & 222 & 0 \\
\hline 62 & Gastric adenocarcinoma & 19,857 & 29 & 0 \\
\hline 63 & Gastric adenocarcinoma & 23,224 & 142 & 0 \\
\hline 64 & Adult gastritis & 5,726 & 271 & 0 \\
\hline 65 & Adult gastritis & 7,612 & 66 & 0 \\
\hline 66 & Adult gastritis & 1,445 & 0 & 0 \\
\hline 67 & Adult gastritis & 6,529 & 3 & 0 \\
\hline 68 & Adult gastritis & 1,299 & 108 & 0 \\
\hline 69 & Pediatric gastritis & 401 & 0 & 0 \\
\hline 70 & Pediatric gastritis & 558 & 18 & 0 \\
\hline 71 & Pediatric gastritis & 136 & 37 & 0 \\
\hline 72 & Pediatric gastritis & 317 & 0 & 0 \\
\hline 73 & Crohn's disease & 1,238 & 0 & 0 \\
\hline 74 & Crohn's disease & 9,278 & 10 & 0 \\
\hline 75 & Crohn's disease & 277 & 0 & 0 \\
\hline 76 & Crohn's disease & 5,568 & 0 & 0 \\
\hline 77 & Ulcerative colitis & 7,035 & 71 & 0 \\
\hline 78 & Ulcerative colitis & 748 & 2,406 & 0 \\
\hline 79 & Ulcerative colitis & 33,311 & 0 & 0 \\
\hline 80 & Ulcerative colitis & 6,488 & 77 & 0 \\
\hline 81 & Meningioma & 27,956 & 0.4 & 0 \\
\hline 82 & Meningioma & 54,614 & 0 & 0 \\
\hline 83 & Normal gastric mucosa & 5,150 & 0 & 0 \\
\hline 84 & Normal gastric mucosa & 11,326 & 0 & 0 \\
\hline 85 & Normal colon mucosa & 7,686 & 3 & 0 \\
\hline 86 & Normal colon mucosa & 9,853 & 0 & 0 \\
\hline
\end{tabular}


Table 3. EBV DNA and human DNA control levels in the AGS-B95-HygB gastric cancer cell line before and after WZhet plasmid transfection

\begin{tabular}{lclc}
\hline & $\begin{array}{l}\text { APOB control } \\
\text { (cellular ge- } \\
\text { nomes, n) }\end{array}$ & $\begin{array}{l}\text { BamH1W } \\
\text { Q-PCR (EBV } \\
\text { genomes, n) }\end{array}$ & $\begin{array}{l}\text { WZhet Q-PCR } \\
\text { (rearranged EBV } \\
\text { genomes, } \mathrm{n})\end{array}$ \\
\hline $\begin{array}{l}\text { Before WZhet plasmid transfection } \\
\text { Cells }\end{array}$ & 90,359 & 385,904 & 1,476 \\
$\quad$ Supernatant & 987 & 86,460 & 2 \\
$\begin{array}{l}\text { After WZhet plasmid transfection } \\
\quad \text { Cells }\end{array}$ & 67,602 & 460,256 & $4,182,500$ \\
$\quad$ Supernatant & 791 & 207,984 & $1,020,427$ \\
\hline
\end{tabular}

All values represent the number of genomes (i.e., cellular, EBV, or rearranged EBV) per PCR. assayed for WZhet DNA and were also tested for traditional EBV viral load by BamH1W Q-PCR. The EBV-related disorders included AIDS lymphoma $(n=10)$, EBVpositive post-transplant lymphoproliferative disorder $(\mathrm{n}=6)$, and infectious mononucleosis $(\mathrm{n}=12)$ cases having plasma $B a m H 1 W$ viral loads ranging from 0 to 81,000 copies $/ \mathrm{ml}$ for the AIDS lymphoma cases, from 308 to 119,000 copies/ml for post-transplant lymphoproliferative disorders, and from 49 to 13,000 copies/ml for infectious mononucleosis cases. In contrast, the healthy blood donors $(\mathrm{n}=9)$ had no detectable plasma BamH1W DNA to a sensitivity of 5 copies of EBV DNA per PCR, which translates to no BamH1W DNA to a sensitivity of 250 copies $/ \mathrm{ml}$ of plasma. To show that DNA was extracted from plasma and that no significant inhibitors were present, each plasma sample had been spiked with an exogenous non-human DNA prior to extraction, and this spiked DNA was consistently amplified among the 37 plasma samples. The absence of WZhet in all 37 plasma samples as well as all 287 biopsy tissues implies that WZhet is not commonly present in the spectrum of lesions evaluated in vivo even when EBV infection is abundantly present as shown by traditional EBER or EBV viral load assays.

\section{Detection of WZhet DNA in vitro}

The failure to detect WZhet DNA in any of the biopsy or plasma samples examined suggests that this defective form of EBV is rare in vivo. An alternative explanation for our failure to detect WZhet could be technical failure of our assay. In particular, the plasmid insert used for design and control of our assay may not represent the typical WZhet structure that is present in vivo even though it was cloned from the prototypic P3HR1 cell line which, in turn, was derived from a human lymphoma. It should be noted, however, that this plasmid amplified with all three of our Q-PCR assays (targeting BZLF1, BamH1W, and WZhet), confirming these sequences were present.

To show that the WZhet plasmid could induce EBV replication in vitro, the plasmid was transfected into an EBV-infected gastric cancer cell line, AGS-B95-HygB, which was then examined for the effect on expression of replicative viral genes (BZLF1 and BMRF1) and on the level of intact virions in the supernatant. Before transfection was performed, baseline tests were performed on the AGS-B95-HygB using six EBV Q-PCR assays that target six disparate segments of the viral genome. The AGSB95-HygB line had high viral load by all six Q-PCR assays. WZhet DNA was also detected by Q-PCR, suggesting that WZhet is produced in infected cells that are cultured in vitro where the human immune response is absent (table 3). Furthermore, EBER in situ hybridization showed EBER expression in $90 \%$ of the AGS-B95-HygB confirming that these cells were indeed infected. BZLF1 and BMRF1 histochemical stains showed that approximately $35 \%$ of cells expressed these replicative viral proteins at baseline.

Despite the baseline presence of WZhet DNA, a transient transfection was performed to determine if viral replication could be further induced by the WZhet plasmid. As shown in table 3, successful transfection of the WZhet plasmid occurred as shown by increased levels of WZhet by Q-PCR of DNA extracted from cell pellets. Total EBV genomes, as measured by BamH1W levels, likewise rose upon transfection, particularly in the supernatant where EBV levels rose more than 2-fold.

To determine if the viral DNA in the supernatant represented encapsidated virions, virion production was determined by measuring BamH1W load by Q-PCR in the supernatant before and after treating with DNase I en- 


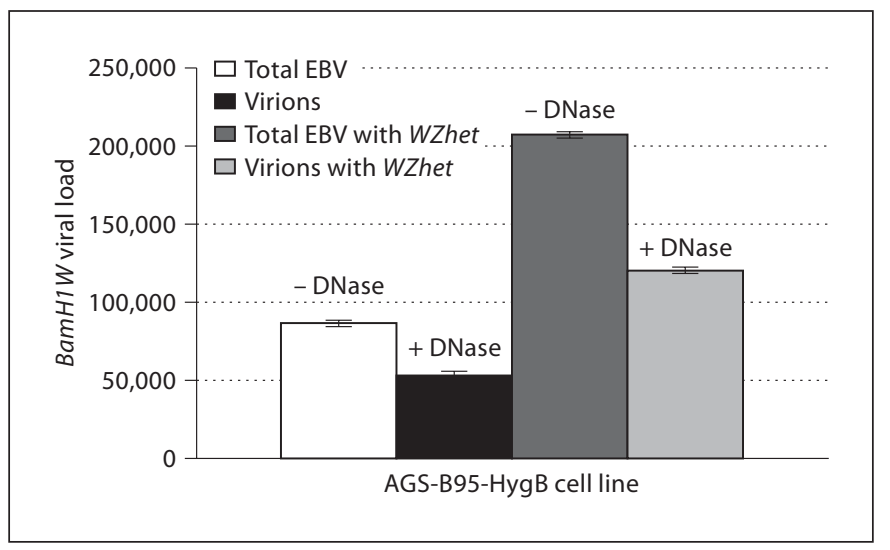

Fig. 2. EBV WZhet plasmid induces viral replication in AGS-B95HygB gastric cancer cells. A large percentage of EBV DNA was not digested by DNase I in AGS-B95-HygB cell supernatant, suggesting active viral replication with virion production. WZhet plasmid transfection more than doubled the number of virions produced by AGS-B95-HygB cells.

zyme. Our prior validation work showed that the capsid protects virions from digestion by DNase I enzyme, so any detectable EBV DNA remaining in the supernatant post-digestion represents virion DNA. A substantial proportion of the viral DNA (57\%) was DNase I-resistant, suggesting that virion production was induced by AGSB95-HygB cells upon WZhet transfection (fig. 2). Interestingly, both naked EBV DNA and encapsidated EBV DNA rose in equal proportions after transfection, whereas human $A P O B$ levels did not rise, implying that the naked DNA is not derived from dying cells rather it appears to represent EBV DNA that failed to acquire a capsid. These findings demonstrate that the WZhet plasmid can induce viral replication when coexpressed with the wildtype EBV genome.

\section{Discussion}

In this study, there was no evidence that human tissues contain the WZhet form of the EBV genome when tested for by a novel Q-PCR assay. No WZhet DNA was detected in any of the benign $(n=134)$ or malignant $(n=153)$ paraffin-embedded tissues screened in our study, nor was it found in plasma samples from patients with EBVrelated disorders $(n=28)$ or healthy controls $(n=9)$. This result implies that the rearranged, partially deleted WZhet DNA is rarely present in human tissues. This finding is important because it refutes the postulate that this atypical form of EBV DNA is commonly present in human tissues that were negative for EBV by more traditional laboratory tests. Furthermore, it implies that WZhet does not commonly coexist with the more traditional EBER-expressing viral genome in several types of lesions that have not been previously examined for presence of WZhet. Furthermore, it implies that WZhet is not commonly present in several types of EBV-related tumors that have not been previously examined for coexistence of WZhet.

Other novel aspects of this study were (1) the development and application of a real-time PCR assay to detect and quantify WZhet, and (2) the first demonstration that epithelial cells are susceptible to induction of lytic viral replication upon transfection by WZhet, whereas prior studies had shown this effect only in lymphoid cells. The rather modest extent of viral induction in AGS epithelial cells was similar to the modest degree of rise in EBV DNA reported when B95.8 lymphoid cell lines, which also harbor baseline viral replication, are induced to replicate further by $12-O$-tetradecanoylphorbol-13-acetate (TPA) [27].

Our clinical findings are somewhat at odds with several previous studies that reported finding WZhet DNA in Burkitt lymphoma, oropharyngeal lesions, EBER-negative and EBER-positive Hodgkin lymphoma, thymic carcinoma, and idiopathic pulmonary fibrosis $[6,13,15$, $16,19,20]$. In support of previous findings, Kelly et al. [13, 28] detected WZhet DNA in the peripheral blood and lung tissue of patients suffering from idiopathic pulmonary fibrosis, although the role of EBV in idiopathic pulmonary fibrosis remains uncertain [29]. Kelly et al. [13] also demonstrated that WZhet DNA was always associated with the presence of other EBV DNA, suggesting that the defective viral genome cannot exist without the standard EBV genome. It should be noted that the current study did not include pulmonary fibrosis and several other disease entities with which WZhet was previously associated.

In agreement with our study, Knecht and Odermatt [30] also found no detectable WZhet DNA in EBV-positive Hodgkin lymphoma, and the discrepancy with prior work was explained, at least in part, by a difference in the age of patients, since Gan et al. [6] had shown WZhet DNA on patients who were less than 21 years old at diagnosis whereas Knecht and Odermatt [30] studied adults. Loss of defective genomes was hypothesized to correlate with differences in immunity between children and adults [30]. 
Technical factors could also explain the observed discrepancies. Prior studies generally used PCR followed by Southern blot analysis, and ours is the first study to use quantitative PCR $[14,15,17,20]$. One cannot exclude the possibility that naturally occurring WZhet has alternative recombination junctions or polymorphisms that render it non-amplifiable by our assay, particularly since our assay amplifies a segment of only $149 \mathrm{bp}$ flanking the recombination site within the P3HR1 standard. In support of the validity of our new assay is the detection of WZhet in infected AGS cells as well as detection of prototypic WZhet derived from P3HR1 cells. Assay specificity was assured by application of an internal TaqMan probe that simultaneously permits quantification of accumulating amplicons against a standard prepared from a plasmid insert of the prototypic P3HR1 Burkitt lymphoma cell line. Our assay was sensitive to as few as 10 copies of WZhet per PCR, which is probably similar to the sensitivity levels achieved in prior studies in which PCR followed by Southern blot analysis was used, although prior work was done on fresh or frozen tissue as opposed to the paraffin-embedded tissue that we targeted. To assure that amplifiable DNA was recovered, we applied a second PCR of the human $A P O B$ gene that verified the efficacy of DNA extraction and amplification from each paraffin-embedded tissue.

WZhet has been shown to be unstable in uninfected cell lines as well as in the P3HR1 Burkitt cell line. So, even if WZhet were formed in vivo, it could be lost, particularly if it activates viral replication and thereby elicits a host immune response [31-35]. In this regard, one might expect to see it more commonly in immunocompromised individuals where uncontested survival of infected cells appears to be more frequent. However, WZhet was not detectable in AIDS or allogenic transplant patients, even those who harbored EBV-related malignancies and who were clearly unable to control the proliferation of latently infected cells. Furthermore, WZhet was not detected in our post-transplant lymphoproliferations or in two ulcerative colitis tissues focally expressing the lytic viral proteins BZLF1 and BMRF1 (data not shown), suggesting that WZhet is not the explanation for activated infection in these lesions. Finally, WZhet was not detected in primary EBV infection even though infectious mononucleosis patients are only just developing the antibody and cell-mediated immune reactions that will protect them from rampant latent and lytic EBV infection for the duration of their lives. In contrast to the in vivo samples, WZhet DNA was detected in cultured AGS-B95-HygB gastric cancer cells. This supports the hypothesis that WZhet DNA occurs in the absence of selective pressures enforced by a host immune system.

In summary, our findings support a role for EBV WZhet DNA in inducing viral replication in vitro. However, our inability to detect EBV WZhet DNA in any of 324 plasma or tissue samples, including those with latent or lytic EBV infection, suggests that either WZhet is not formed in the spectrum of lesions examined in vivo or that it exists only transiently. The findings serve to emphasize that in vitro EBV infection in cell culture does not necessarily mimic in vivo EBV infection in a living host.

\section{Acknowledgements}

This study was sponsored by grants from the National Cancer Institute (CA107966) and from the NCI Environmental Pathology Training Program (T32-ES07017). The authors thank our colleagues who provided samples for this study, including Jennifer Webster-Cyriaque, DDS, Bruce Israel, MD, Douglas Morgan, $\mathrm{MD}, \mathrm{MPH}$, Ricardo Dominguez, MD, Leigh B. Thorne, MD, YouJun Shen, MD, Mari Mino-Kenudson, MD, and Gregory Lauwers, MD. We also thank the Anatomic Pathology Core Laboratory of the UNC Department of Pathology and Laboratory Medicine for technical support.

\section{References}

1 Gulley ML: Molecular diagnosis of EpsteinBarr virus-related diseases. J Mol Diagn 2001;3:1-10.

- Thorley-Lawson DA: Epstein-Barr virus: exploiting the immune system. Nat Rev Immunol 2001;1:75-82.

3 Sixbey J: Epstein-Barr virus DNA loss from tumor cells and the geography of Burkitt's lymphoma. Epstein-Barr Virus Rep 2000;7: $37-40$.

Prevalence and Effect of Epstein-Barr Virus WZhet
-4 Fan H, Schichman SA, Swinnen LJ, Nicholls JM, Eagan PA, Luther M, Gulley ML: Analytic validation of a competitive polymerase chain reaction assay for measuring EpsteinBarr viral load. Diagn Mol Pathol 2001;10: 255-264.

5 Grinstein S, Preciado MV, Gattuso P, Chabay PA, Warren WH, De Matteo E, Gould VE: Demonstration of Epstein-Barr virus in carcinomas of various sites. Cancer Res 2002;62: 4876-4878.
6 Gan YJ, Razzouk BI, Su T, Sixbey JW: A defective, rearranged Epstein-Barr virus genome in EBER-negative and EBER-positive Hodgkin's disease. Am J Pathol 2002;160: 781-786.

7 Chen PC, Pan CC, Yang AH, Wang LS, Chiang H: Detection of Epstein-Barr virus genome within thymic epithelial tumours in Taiwanese patients by nested PCR, PCR in situ hybridization, and RNA in situ hybridization. J Pathol 2002;197:684-688. 
8 Korabecna M, Ludvikova M, Skalova A: Molecular diagnosis of Epstein-Barr virus in paraffin-embedded tissues of tumors with abundant lymphoid infiltration. Neoplasma 2003;50:8-12.

9 Lauritzen AF, Hording U, Nielsen HW: Epstein-Barr virus and Hodgkin's disease: a comparative immunological, in situ hybridization, and polymerase chain reaction study. APMIS 1994;102:495-500.

-10 Van Beek J, zur Hausen A, Kranenbarg EK, Warring RJ, Bloemena E, Craanen ME, van de Velde CJ, Middeldorp JM, Meijer CJ, van den Brule AJ: A rapid and reliable enzyme immunoassay PCR-based screening method to identify EBV-carrying gastric carcinomas. Mod Pathol 2002;15:870-877.

-11 Countryman J, Miller G: Activation of expression of latent Epstein-Barr herpesvirus after gene transfer with a small cloned subfragment of heterogeneous viral DNA. Proc Natl Acad Sci USA 1985;82:4085-4089.

$\checkmark 12$ Rooney C, Taylor N, Countryman J, Jenson H, Kolman J, Miller G: Genome rearrangements activate the Epstein-Barr virus gene whose product disrupts latency. Proc Natl Acad Sci USA 1988;85:9801-9805.

-13 Kelly BG, Lok SS, Hasleton PS, Egan JJ, Stewart JP: A rearranged form of Epstein-Barr virus DNA is associated with idiopathic pulmonary fibrosis. Am J Respir Crit Care Med 2002;166:510-513.

14 Heston L, Rabson M, Brown N, Miller G: New Epstein-Barr virus variants from cellular subclones of P3J-HR-1 Burkitt lymphoma. Nature 1982;295:160-163.

15 Jenson HB, Farrell PJ, Miller G: Sequences of the Epstein-Barr virus (EBV) large internal repeat form the center of a 16-kilobase-pair palindrome of EBV (P3HR-1) heterogeneous DNA. J Virol 1987;61:1495-1506.

-16 Patton DF, Ribeiro RC, Jenkins JJ, Sixbey JW: Thymic carcinoma with a defective EpsteinBarr virus encoding the BZLF1 trans-activator. J Infect Dis 1994;170:7-12.

-17 Rabson M, Heston L, Miller G: Identification of a rare Epstein-Barr virus variant that enhances early antigen expression in Raji cells. Proc Natl Acad Sci USA 1983;80:2762-2766.
18 Srinivas SK, Sample JT, Sixbey JW: Spontaneous loss of viral episomes accompanying Epstein-Barr virus reactivation in a Burkitt's lymphoma cell line. J Infect Dis 1998;177: 1705-1709.

19 Gan YJ, Shirley P, Zeng Y, Sixbey JW: Human oropharyngeal lesions with a defective Epstein-Barr virus that disrupts viral latency. J Infect Dis 1993;168:1349-1355.

20 Cho MS, Bornkamm GW, zur Hausen H: Structure of defective DNA molecules in Epstein-Barr virus preparations from P3HR-1 cells. J Virol 1984;51:199-207.

21 Ryan JL, Fan H, Glaser SL, Schichman SA Raab-Traub N, Gulley ML: Epstein-Barr virus quantitation by real-time PCR targeting multiple gene segments: a novel approach to screen for the virus in paraffin-embedded tissue and plasma. J Mol Diagn 2004;6:378385.

22 Ryan JL, Fan H, Swinnen LJ, Schichman SA, Raab-Traub N, Covington M, Elmore S, Gulley ML: Epstein-Barr virus (EBV) DNA in plasma is not encapsidated in patients with EBV-related malignancies. Diagn Mol Pathol 2004;13:61-68.

-23 Hong GK, Delecluse HJ, Gruffat H, Morrison TE, Feng WH, Sergeant A, Kenney SC: The BRRF1 early gene of Epstein-Barr virus encodes a transcription factor that enhances induction of lytic infection by BRLF1. J Virol 2004;78:4983-4992.

24 Morrison TE, Mauser A, Klingelhutz A, Kenney SC: Epstein-Barr virus immediateearly protein BZLF1 inhibits tumor necrosis factor- $\alpha$-induced signaling and apoptosis by downregulating tumor necrosis factor receptor 1. J Virol 2004;78:544-549.

25 Neuhierl B, Feederle R, Hammerschmidt W, Delecluse HJ: Glycoprotein gp110 of EpsteinBarr virus determines viral tropism and efficiency of infection. Proc Natl Acad Sci USA 2002;99:15036-15041.

26 Ling PD, Vilchez RA, Keitel WA, Poston DG, Peng RS, White ZS, Visnegarwala F, Lewis DE, Butel JS: Epstein-Barr virus DNA loads in adult human immunodeficiency virus type 1-infected patients receiving highly active antiretroviral therapy. Clin Infect Dis 2003;37:1244-1249.

-27 Pan YR, Fang CY, Chang YS, Chang HY: Analysis of Epstein-Barr virus gene expression upon phorbol ester and hydroxyurea treatment by real-time quantitative PCR Arch Virol 2005;150:755-770.
28 Stewart JP, Egan JJ, Ross AJ, Kelly BG, Lok SS, Hasleton PS, Woodcock AA: The detection of Epstein-Barr virus DNA in lung tissue from patients with idiopathic pulmonary fibrosis. Am J Respir Crit Care Med 1999; 159:1336-1341.

29 Hayakawa H, Shirai M, Uchiyama H, Imokawa S, Suda T, Chida K, Muro H: Lack of evidence for a role of Epstein-Barr virus in the increase of lung cancer in idiopathic pulmonary fibrosis. Respir Med 2003;97:281284.

30 Knecht H, Odermatt BF: Rearranged Epstein-Barr virus genome in Hodgkin's disease and angioimmunoblastic lymphadenopathy: Swiss results. Am J Pathol 2003; 163:369-370.

>31 Durda PJ, Sullivan M, Kieff E, Pearson GR, Rabin H: An enzyme-linked immunosorbent assay for the measurement of human IgA antibody responses to Epstein-Barr virus membrane antigen. Intervirology 1993; 36:11-19.

-32 Hadar T, Rahima M, Kahan E, Sidi J, Rakowsky E, Sarov B, Sarov I: Significance of specific Epstein-Barr virus IgA and elevated IgG antibodies to viral capsid antigens in nasopharyngeal carcinoma patients. J Med Virol 1986;20:329-339.

-33 Xu J, Ahmad A, Blagdon M, D’Addario M, Jones JF, Dolcetti R, Vaccher E, Prasad U, Menezes J: The Epstein-Barr virus (EBV) major envelope glycoprotein gp350/220-specific antibody reactivities in the sera of patients with different EBV-associated diseases. Int J Cancer 1998;79:481-486.

34 Yip TT, Ngan RK, Lau WH, Poon YF, Joab I, Cochet C, Cheng AK: A possible prognostic role of immunoglobulin-G antibody against recombinant Epstein-Barr virus BZLF-1 transactivator protein ZEBRA in patients with nasopharyngeal carcinoma. Cancer 1994;74:2414-2424.

35 Packham G, Brimmell M, Cook D, Sinclair AJ, Farrell PJ: Strain variation in EpsteinBarr virus immediate early genes. Virology 1993;192:541-550. 